\title{
Implementation of Profile Matching Methods In A Mobile Based Adolescent Nutritional Assesment Systems
}

\author{
B.A Herlambang ${ }^{1}$, F.M Dewanto ${ }^{2}$, A.T Harjanta ${ }^{3}$,V.A.V Setyawati ${ }^{4}$ \\ ${ }^{1}$ Universitas PGRI Semarang/Program Studi Informatika - Fakultas Teknik \& Informatika \\ Jl. Sidodadi Timur No.24 Semarang, e-mail: bambangherlambang@upgris.ac.id \\ ${ }^{2}$ Universitas PGRI Semarang/Program Studi Informatika - Fakultas Teknik \& Informatika \\ Jl. Sidodadi Timur No. 24 Semarang, e-mail: febrianmd@upgris.ac.id@upgris.ac.id \\ ${ }^{3}$ Universitas PGRI Semarang/Program Studi Informatika - Fakultas Teknik \& Informatika \\ Jl. Sidodadi Timur No.24 Semarang, e-mail: aristrijaka@upgris.ac.id@upgris.ac.id \\ ${ }^{4}$ Universitas Dian Nuswantoro/Program Studi Kesehatan Masyarakat - Fakultas Kesehatan \\ Jl. Sidodadi Timur No. 24 Semarang, e-mail: vilda.setyawati@dsn.dinus.ac.id
}

\section{ARTICLE INFO}

Article history:

Received 23 July 2018

Received in revised form 30 July 2018

Accepted 3 Agustus 2018

Available online 17 Agustus 2018

\section{ABSTRACT}

The use of mobile apps in knowing the problems as early as possible was considered effective. The application of mobile applications required today was an application that could help determine various health problems. The health problems discussed in this study were the nutritional status of adolescents. The method of measuring the nutritional status used was the BMI / A method. Profile Matching method in built mobile application is used to rank the nutritional status of adolescents. Aspect of nutritional status assessment in this research was physical aspect (BMI/A and Physical Activity) with $70 \%$ and Non-Physical Aspect (Eating \& Socioeconomic Aspect) with 30\% assessment percentage. Core factor in the determination of nutritional status were the Category of BMI and Frequency of Eating. While, secondary factor were food pattern and socio Economics. The results of mobile application implementation with Profile Matching method in this research there were several forms for the process of ranking the status of Adolescent Nutrition. The form contained in Administrator features include Administrator Login Form, Aspect Setup Form, Sub Aspect Setting Form, Physical Activity Setting Form, Form Setting Frequency Diet, Setting Form BMI/A, Economic Condition Set Form, Setting Form Weight Gap Value. In the User Features there was an Assessment form and a page to see the results of ranking the nutritional status of adolescents.

Keyword : System Of Determination, Nutritional Status, Adolescences, Profile Matching, BMI/A, Mobile 


\section{Pendahuluan}

Seiring dengan perkembangan teknologi informasi, aplikasi mobile secara luas diterapkan pada berbagai bidang. Penggunaan aplikasi mobile dianggap efektif untuk membantu pengguna dalam mengetahui masalah sedini mungkin. Salah satu penerapan aplikasi mobile yang dibutuhkan saat ini adalah sebuah aplikasi yang dapat membantu untuk menentukan berbagai masalah kesehatan. Masalah kesehatan yang dibahas dalam penelitian ini adalah status gizi remaja. Menurut Thornburg, usia remaja adalah dari usia 13 tahun sampai 21 tahun yang dibagi menjadi 3 tahapan antara lain pertama remaja awal (13-14 tahun), kedua remaja tengah (15-17 tahun) dan ketiga remaja akhir (18-21 tahun) [1]. Penelitian tahun 2014 pada remaja SMA Kota Semarang menunjukkan pengetahuan gizi remaja cukup (56,7\%), dan semua berperilaku makan kurang baik (100\%) [2]. Ditambah penelitian tahun 2015 menunjukkan, 53,8 \% mengalami malnutrisi dan 95,8 \% sering mengkonsumsi junk food dan fast food, dimana definisi sering adalah lebih dari 3 kali selama seminggu [3]. Penellitian [4] berdasarkan pada pengujian yang telah dilakukan masih perlu dikaji dan dikembangkan lagi agar kinerjanya lebih baik, selain itu pengujian dan implementasi lebih lanjut di lapangan sesuai kondisi masalah yang sebenarnya diperlukan untuk membuktikan performa sistem dan keakuratan hasil perhitungan.

Dalam penelitian masih sebatas menghitung nilai derajat keanggotaan dari variabel indeks berat badan menurut umur $(\mathrm{BB} / \mathrm{U})$, tinggi badan menurut umur $(\mathrm{TB} / \mathrm{U})$, dan berat badan menurut tinggi badan $(\mathrm{BB} / \mathrm{TB})$ untuk balita. Sistem penentuan status gizi remaja yang dikembangkan dalam penelitian ini selain dapat digunakan untuk mengukur status gizi remaja dengan mengimplementasikan metode profile matching dalam aplikasi mobile yang dibangun juga dapat digunakan untuk perangkingan status gizi remaja yang telah diukur dengan menggunakan kaidah pengukuran IMT/U (Index Massa Tubuh Menurut Umur). Metode Profile Matching merupakan metode yang dapat digunakan sebagai mekanisme dalam pengambilan keputusan dengan mengasumsikan bahwa terdapat tingkat variabel prediktor yang ideal yang harus dipenuhi oleh subyek yang diteliti, bukannya tingkat minimal yang harus dipenuhi atau dilewati [6]. Profile Matching merupakan proses membandingkan antara nilai data aktual dari suatu profile yang akan dinilai dengan nilai profil yang diharapkan, sehingga dapat diketahui perbedaan gap, semakin kecil nilai gap maka bobot nilainya.semakin besar [7]. Dengan mengetahui status gizi remaja akan dapat merencanakan atau memperbaiki kondisi yang menyebabkan ketidak normalan status gizinya. Penggunaan sistem aplikasi berbasis mobile dalam penelitian ini untuk mengukur status gizi remaja. Implementasi dari metode Profile Matching ini yaitu untuk pengambilan keputusan berkaitan dengan perangkingan status gizi remaja.

\section{Metode Penelitian}

\section{A. Metode Pengukuran Status Gizi}

Metode pengukuran status gizi yang digunakan adalah metode IMT/ U. IMT merupakan salah satu indeks pengukuran status gizi yang biasa digunakan untuk mengukur status gizi usia remaja dan dewasa. Penilaian status gizi pada remaja pada subjek penelitian ini dengan menggunakan Indeks Massa Tubuh (BMI). Indeks massa tubuh (IMT) merupakan nilai yang diambil dari perhitungan antara berat badan (BB) dan tinggi badan (TB) seseorang. IMT dipercayai dapat menjadi indikator atau mengambarkan kadar adipositas dalam tubuh seseorang. IMT tidak mengukur lemak tubuh secara langsung, tetapi penelitian menunjukkan bahwa IMT berkorelasi dengan pengukuran secara langsung lemak tubuh seperti underwater weighing dan dual energy x-ray absorbtiometry. IMT merupakan altenatif untuk tindakan pengukuran lemak tubuh karena murah serta metode skrining kategori berat badan yang mudah dilakukan. 
Untuk mengetahui nilai BMI ini, dapat dihitung dengan rumus berikut [8]:

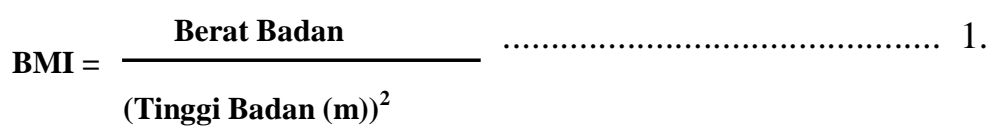

Hasil dari perhitungan tersebut, kemudian dikategorikan untuk menentukkan status gizi [8]. Dalam pengukuran status gizi bagi remaja dengan menggunakan IMT/U diperlukan pengukuran Skor simpang baku (Z-score) yang diperoleh dari Nilai Individual Subjek (NIS) dengan nilai median Baku Rujukan (NMBR) pada umur yang bersangkutan, hasilnya dibagi dengan nilai simpang baku rujukan, sehingga dapat dirumuskan sebagai berikut [8]:

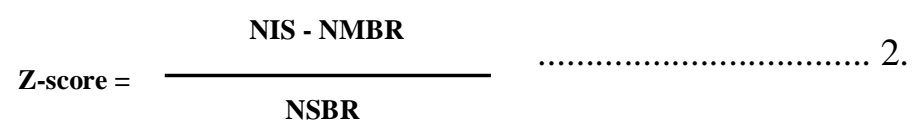

Penggunaan rumus diatas untuk NMBR status gizi remaja dengan menggunakan kaedah pengukuran IMT/U dapat dilihat pada lampiran Kepmenkes RI No: 1995/ MENKES/SK/XII/2010 sebagai berikut:

Tabel 1: Nilai Rujukan Standar Z-Score

\begin{tabular}{cl}
\hline Range Nilai & \multicolumn{1}{c}{ Kategori } \\
\hline -2SD - 1SD & Normal \\
\hline >1SD - 2SD & Gemuk \\
\hline -3SD - <2SD & Kurus \\
\hline$>2$ SD & Obesitas \\
\hline <-3SD & Sangat Kurus \\
\hline
\end{tabular}

B. Metode Profile Matching

Penghitungan Profile dimulai mendefinisikan nilai minimum untuk tiap variabel atau yang disebut dengan gap. Gap yang telah diperoleh kemudian diberi nilai bobot, semakin kecil nilai gap maka semakin besar nilai bobotnya. Selanjutnya bobot dari variabel akan dihitung nilai rata-ratanya sesuai dengan type/ jenis kriteria dari variabel tersebut. Terdapat dua type/ jenis variabel yaitu Core Factor dan Secondary Factor. Jumlah komposisi Core Factor dan Secondary Factor $=100 \%$. Langkah-langkah metode Profile Matching yang pertama adalah menentukan Bobot Nilai Gap. Bobot nilai masing-masing aspek dengan menggunakan bobot nilai yang telah ditentukan bagi masing-masing aspek itu sendiri [6]. Dalam penelitian ini inputan pembobotannya adalah selisih dari Profil Remaja dan Profil status Gizi.

Selanjutnya melakukan pemetaan Gapyang merupakan perbedaan antara profil Remaja dengan profil Status Gizi. Gap = Profil Remaja - Profil Status Gizi. Nilai gap yang diperoleh kemudian dilakukan pencocokan dengan tabel bobot Gap. Langkah selanjutnya adalah melakukan perhitungan Core Factor dan Secondary Factor. Setelah menentukan bobot nilai gap untuk aspek yang dibutuhkan, kemudian tiap aspek dikelompokkan lagi menjadi dua kelompok yaitu core factor dan secondary factor. Core Factor (Faktor Utama), yaitu merupakan kriteria yang paling penting untuk penilaian yang diharapkan dapat memperoleh hasil yang optimal dengan rumus sebagai berikut [6]:

Implementation of Profile Matching Methods in A Mobile Based Adolescent Nutritional Assesment 


\section{Keterangan:}

NFC : Nilai rata-rata core factor

NC : Jumlah total nilai core factor

IC : Jumlah item core factor

Core factor/CF dalam penentuan status gizi ini adalah Kategori IMT. Secondary Factor/SF (faktor pendukung) merupakan item lain yang ada pada core factor atau dengan kata lain merupakan faktor pendukung yang kurang dibutuhkan oleh penilaian.

Keterangan:

NFS : Nilai rata-rata secondary factor

NS : Jumlah total nilai secondary factor

IS : Jumlah item secondary factor

Secondary factor dalam penentuan status gizi ini adalah Tingkat Aktifitas Fisik, Pola makan dan Sosial Ekonomi. Total Nila diperoleh dari prosentase core factor dan secondary factor yang diperkirakan berpengaruh terhadap hasil tiap-tiap profil.

$$
\mathbf{N}=(\mathbf{x}) \% \mathbf{N C F}+(\mathbf{x}) \% \mathbf{N S F}
$$
5.

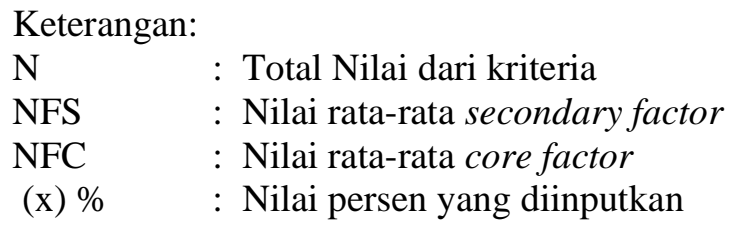

Langkah terakhir adalah Penentuan Rangking. Proses profile matching pada akhirnya akan menghasilkan ranking. Penghitungan nilai ranking mengacu pada hasil perhitungan dengan rumus sebagai berikut :

$$
\text { Ranking }=(\mathbf{x}) \% \text { NMA + (x) \% NSA }
$$
6.

Keterangan :

NMA : Nilai total kriteria Aspek Utama

NSA : Nilai total kriteria Aspek Pendukung

(x) $\% \quad$ : Nilai persen yang diinputkan

\section{Hasil dan Analisa}

Dalam bagian ini akan disimulasikan penghitungan perangkingan untuk menentukan status gizi remaja dengan menggunakan analisis penghitungan Profile Matching. Selanjutnya dari simulasi penghitungan tersebut akan diimplementasikan dalam Aplikasi Penentuan Status Gizi Remaja. 


\subsection{Variabel Penghitungan}

Pada sub bab ini akan disimulasikan penghitungan dengan metode Profile Matching dari variabel-variabel yang dibutuhkan dalam sistem penentuan status gizi remaja. Dalam pemodelan Sistem Penentuan Status Gizi Remaja ini digunakan beberapa variabel penghitungan disajikan dalam tabel 1 berikut ini:

Tabel 1 : Variabel Penghitungan

\begin{tabular}{ccclc}
\hline $\begin{array}{c}\text { ID } \\
\text { Aspek }\end{array}$ & $\begin{array}{c}\text { Nama } \\
\text { Aspek }\end{array}$ & $\begin{array}{c}\text { ID Sub } \\
\text { Aspek }\end{array}$ & $\begin{array}{c}\text { Nama Sub } \\
\text { Aspek }\end{array}$ & $\begin{array}{c}\text { Nilai } \\
\text { Profile }\end{array}$ \\
\hline A001 & Fisik & SA11 & IMT/U & 5 \\
\cline { 3 - 5 } & $(70 \%)$ & SA12 & $\begin{array}{l}\text { Aktifitas } \\
\text { Fisik }\end{array}$ & 3 \\
\hline A002 & Non & SA21 & $\begin{array}{l}\text { Frekuensi } \\
\text { Makan }\end{array}$ & 4 \\
& Fisik & SA22 & $\begin{array}{l}\text { Sosial } \\
\text { ekonomi }\end{array}$ & 2 \\
\cline { 3 - 4 } & $(30 \%)$ & & & \\
\hline
\end{tabular}

Sub Aspek yang ada dalam variabel penghitungan memiliki kategori dan skor seperti yang ada dalam penjelasan berikut ini:

a. IMT/ U

Sub Aspek IMT/ U ini memiliki kategori dan nilai skor untuk masing-masing kategori sebagai berikut:

Tabel 2 : Skor Kategori IMT/U

\begin{tabular}{clc}
\hline No & Kategori & Skor \\
\hline $\mathbf{1}$ & Normal & 5 \\
\hline $\mathbf{2}$ & Gemuk & 4 \\
\hline $\mathbf{3}$ & Kurus & 4 \\
\hline $\mathbf{4}$ & Obesitas & 3 \\
\hline $\mathbf{5}$ & Sangat Kurus & 3 \\
\hline
\end{tabular}

b. Aktifitas Fisik

Sub Aspek Aktifitas fisik ini memiliki kategori dan nilai skor untuk masing-masing ketegori sebagai berikut:

Tabel 3: Skor Kategori Aktifitas Fisik/ Olah Raga

\begin{tabular}{ccc}
\hline No & Kategori & Skor \\
\hline $\mathbf{1}$ & 2x Seminggu & 4 \\
\hline $\mathbf{2}$ & 1x Seminggu & 3 \\
\hline $\mathbf{3}$ & 0x Seminggu & 2 \\
\hline
\end{tabular}

Implementation of Profile Matching Methods in A Mobile Based Adolescent Nutritional Assesment Systems (B.A Herlambang) 
c. Frekuensi Makan

Sub Aspek Frekuensi Makan ini memiliki kategori dan nilai skor untuk masing-masing ketegori sebagai berikut:

Tabel 4: Skor Kategori Frekuensi Makan

\begin{tabular}{clc}
\hline No & Kategori & Skor \\
\hline $\mathbf{1}$ & $>3$ x Sehari & 3 \\
\hline $\mathbf{2}$ & 3x Sehari & 4 \\
\hline $\mathbf{3}$ & $<3 \times$ Sehari & 2 \\
\hline
\end{tabular}

d. Sosial Ekonomi

Sub Aspek Sosial Ekonomi ini merupakan penghasilan dari orang tua remaja yang melakukan assesment, memiliki kategori dan nilai skor untuk masing-masing ketegori sebagai berikut:

Tabel 5 : Skor Kategori Sosial Ekonomi

\begin{tabular}{ccc}
\hline No & Kategori & Skor \\
\hline $\mathbf{1}$ & $>$ Rp.5000.000 & 3 \\
\hline $\mathbf{2}$ & Rp.3000.000 sd Rp.5000.000 & 2 \\
\hline $\mathbf{3}$ & $<$ Rp.3.000.000 & 1 \\
\hline
\end{tabular}

\subsection{Proses Penghitungan Pemetaan Gap}

Dalam sub bab ini akan disimulasikan penghitungan gap untuk setiap nilai profile remaja yang dinilai dengan nilai profile standar dari status gizi seperti yang ada dalam tabel berikut ini :

Tabel 6 :Pemetaan Nilai Gap

\begin{tabular}{ccccccc}
\hline \multirow{2}{*}{ No } & ID Remaja & \multicolumn{3}{c}{ A001 } & \multicolumn{3}{c}{ A002 } & \\
\cline { 3 - 7 } & & SA11 & SA12 & SA21 & SA22 & \\
\hline $\mathbf{1}$ & R001 & 4 & 2 & 4 & 3 & Nilai \\
$\mathbf{2}$ & R002 & 5 & 3 & 3 & 3 & Profile \\
\hline $\mathbf{3}$ & R003 & 4 & 3 & 2 & 2 & Remaja \\
\hline Nilai Profile Capaian & $\mathbf{5}$ & $\mathbf{3}$ & $\mathbf{4}$ & $\mathbf{2}$ & \\
\hline $\mathbf{1}$ & R001 & -1 & -1 & 0 & 1 & Nilai \\
$\mathbf{2}$ & R002 & 0 & 0 & -1 & 1 & Gap \\
\hline $\mathbf{3}$ & R003 & -1 & 0 & -2 & 0 & \\
\hline
\end{tabular}

\subsection{Pembotan Nilai Gap}

Setelah di peroleh gap dari masing-masing calon tersebut, setiap profil calon desa mandiri di beri bobot nilai dengan patokan tabel bobot nilai gap. Pembobotan yang digunakan pada penelitian ini dapat dilihat pada tabel 7 berikut ini:

TRANSFORMATIKA Vol. 16, No. 1, Juli 2018: 1-13 
Tabel 7:Pembobotan Nilai Gap

\begin{tabular}{cccl}
\hline No & $\begin{array}{c}\text { Selisih } \\
\text { Gap }\end{array}$ & $\begin{array}{c}\text { Nilai } \\
\text { Bobot }\end{array}$ & \multicolumn{1}{c}{ Keterangan } \\
\hline $\mathbf{1}$ & 0 & 5 & $\begin{array}{l}\text { Nilai sesuai dengan yang } \\
\text { diharapkan }\end{array}$ \\
\hline $\mathbf{2}$ & 1 & 4.5 & Nilai kelebihan 1 tingkat \\
\hline $\mathbf{3}$ & -1 & 4 & Nilai kurang 1 Tingkat \\
\hline $\mathbf{4}$ & 2 & 2.5 & Nilai Kelebihan 2 Tingkat \\
\hline $\mathbf{5}$ & -2 & 2 & Nilai kurang 2 Tingkat \\
\hline
\end{tabular}

Dari proses penghitungan nilai gap pada tabel 4.6 diperoleh hasil pembobotan seperti yang ada pada tabel berikut ini:

Tabel 8: Hasil Pembobotan Nilai Gap

\begin{tabular}{ccccc}
\hline ID Remaja & \multicolumn{2}{c}{ A001 } & \multicolumn{2}{c}{ A002 } \\
\cline { 2 - 5 } & SA11 & SA12 & SA21 & SA22 \\
\hline R001 & 4 & 4 & 5 & 4.5 \\
\hline R002 & 5 & 5 & 4 & 4.5 \\
\hline R003 & 4 & 5 & 2 & 5 \\
\hline
\end{tabular}

\subsection{Penghitungan Nilai Tiap Aspek}

Langkah berikutnya menghitung nilai total dari tiap-tiap aspek aspek, dimana pada sistem menentukan status gizi ini telah ditentukan Nilai Coref actor $(\mathrm{CF})=60 \%$ dan nilai Secondary Factor $(\mathrm{SF})=40 \%$, selanjutnya untuk tipe/ jenis CF atau SF dari faktor yang digunakan pada tiap-tiap kriteria disajikan dalam tabel 9 berikut:

Tabel 9: Pemetaan Core Factor dan Scondary Factor

\begin{tabular}{ccc}
\hline ID Aspek & ID Sub Aspek & Type/Jenis \\
\hline A001 & SA11 & CF \\
\hline A001 & SA12 & SF \\
\hline A002 & SA21 & CF \\
\hline A002 & SA22 & SF \\
\hline
\end{tabular}

Setelah diketahui tipe/ jeni faktor dari tiap kriteria, proses berikutnya adalah melakukan perhitungan nilai total untuk masing-masing aspek dengan rumus:

$$
\mathrm{N}=60 \% \mathrm{NC}+40 \% \mathrm{NS}
$$



berikut:

Penghitungan nilai untuk masing-masing remaja dapat dilihat dalam simulasi sebagai

a. ID Remaja R001

- Aspek Fisik

$$
\begin{aligned}
& =(60 \% * 4)+(40 \% * 4) \\
& =2.4+1.6
\end{aligned}
$$$$
=4
$$

- Aspek Non Fisik

$=(60 \% * 5)+(40 \% * 4.5)$

$=3+1,8$

$=4,8$

b. ID Remaja R002

- Aspek Fisik

$=(60 \% * 5)+(40 \% * 5)$

$=3+2$

$=5$

- Aspek Non Fisik

$=(60 \% * 4)+(40 \% * 4.5)$

$=2.4+1.8$

$=4,2$

c. ID Remaja R003

- Aspek Fisik

$=(60 \% * 4)+(40 \% * 5)$

$=2.4+2$

$=4.4$

- Aspek Non Fisik

$=(60 \% * 2)+(40 \% * 5)$

$=1,2+2$

$=3,2$

Sehingga dapat dipetakan nilai untuk masing-masing aspek dalam tabel berikut ini:

Tabel 10: Nilai Total Tiap Aspek

\begin{tabular}{cccc}
\hline No & ID Remaja & Aspek Fisik & Aspek Non Fisik \\
\hline $\mathbf{1}$ & R001 & 4 & 4.8 \\
\hline $\mathbf{2}$ & R002 & 5 & 4.2 \\
\hline $\mathbf{3}$ & R003 & 4.4 & 3.2 \\
\hline
\end{tabular}

\subsection{Penghitungan Rangking}

Proses Profile Matching akan menghasilkan rangking Status Gizi Remaja. Dalam tahap ini akan dilakukan perhitungan penentuan rangking dengan cara nilai total aspek untuk setiap alternatif dikalikan dengan nilai presentase untuk tiap-tiap aspek, dimana pada penelitian ini digunakan nilai presentase aspek yaitu 70\% Aspek Fisik $+30 \%$ Aspek Non Fisik. Nilai prosentase untuk tiap-tiap aspek dibuat dinamis sehingga dapat disesuaikan sewaktu-waktu jika dibutuhkan. Penenetuan penghitungan rangking dalam penelitian ini $70 \% * \mathrm{AF}+30 \% * \mathrm{NF}$.

TRANSFORMATIKA Vol. 16, No. 1, Juli 2018: 1-13 
Selanjutnya nilai rangking diurutkan dari nilai hasil yang terbesar sampai dengan nilai hasil yang terkecil. Adapun hasil urutan rangking sebagai berikut:

1. ID Remaja R001

$$
\begin{aligned}
\text { Rangking } & =(70 \% * 4)+(30 \% * 4.8) \\
& =2.8+1.44 \\
& =4.24
\end{aligned}
$$

2. ID Remaja R002

$$
\begin{aligned}
\text { Rangking } & =(70 \% * 5)+(30 \% * 4.2) \\
& =3.5+1.26 \\
& =4.76
\end{aligned}
$$

3. ID Remaja R003

$$
\begin{aligned}
\text { Rangking } & =(70 \% * 4.4)+(30 \% * 3.2) \\
& =3.08+0.96 \\
& =4.04
\end{aligned}
$$

\subsection{Implementasi}

Dari rancangan sistem penentuan status gizi yang telah penulis buat dalam penelitian sebelumnya [9] dapat diimplementasikan menjadi Aplikasi Penentuan Status Gizi Remaja dengan metode Profile Matching untuk proses penghitungannya. Aplikasi ini dalamnya terdapat beberapa Form untuk menfasilitasi proses perangkingan status Gizi Remaja dengan metode Profile Matching. Adapun form yang terdapat dalam fitur Administrator antara lain Form Login Administrator, Form Setting Aspek, Form Setting Sub Aspek, Form Setting Aktivitas Fisik, Form Setting Frekuensi Pola Makan, Form Setting IMT/U, Form Setting Kondisi Ekonomi, Form Setting Bobot Nilai Gap. Dalam Fitur User terdapat form Asessment dan halaman untuk melihat hasil perangkingan status gizi remaja.

$\overline{\text { Implementation of Profile Matching Methods in A Mobile Based Adolescent Nutritional Assesment }}$ Systems (B.A Herlambang) 


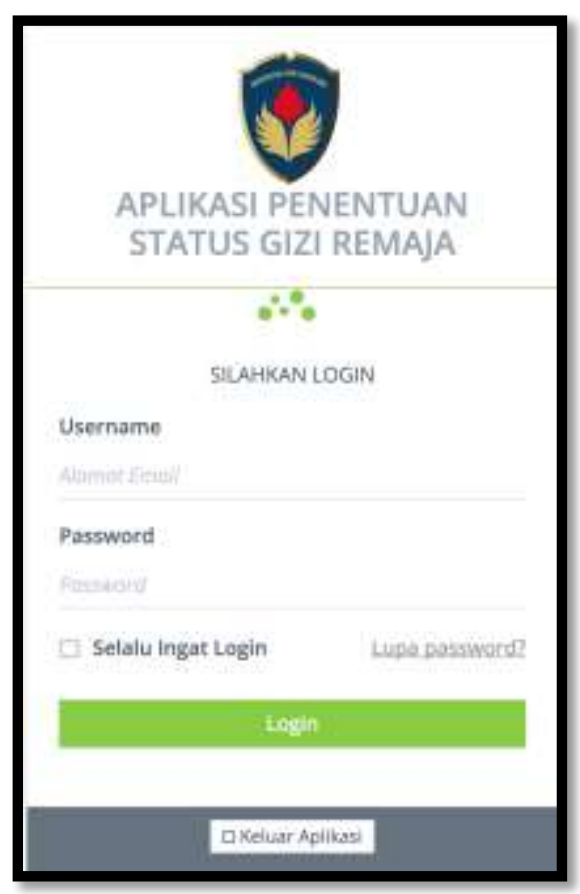

Gambar 1 : Halaman Login

Tampilan diatas merupakan tampilan dari halaman login admin. Admin dapat melakukan input user name dan password yang sesuai sebelum melakukan pengelolaan terhadap nilai core factor ataupun secondary factor yang dapat dikelola dalam Form Setting Sub Aspek, Form Setting Aktivitas Fisik, Form Setting Frekuensi Pola Makan, Form Setting IMT/U, Form Setting Kondisi Ekonomi .

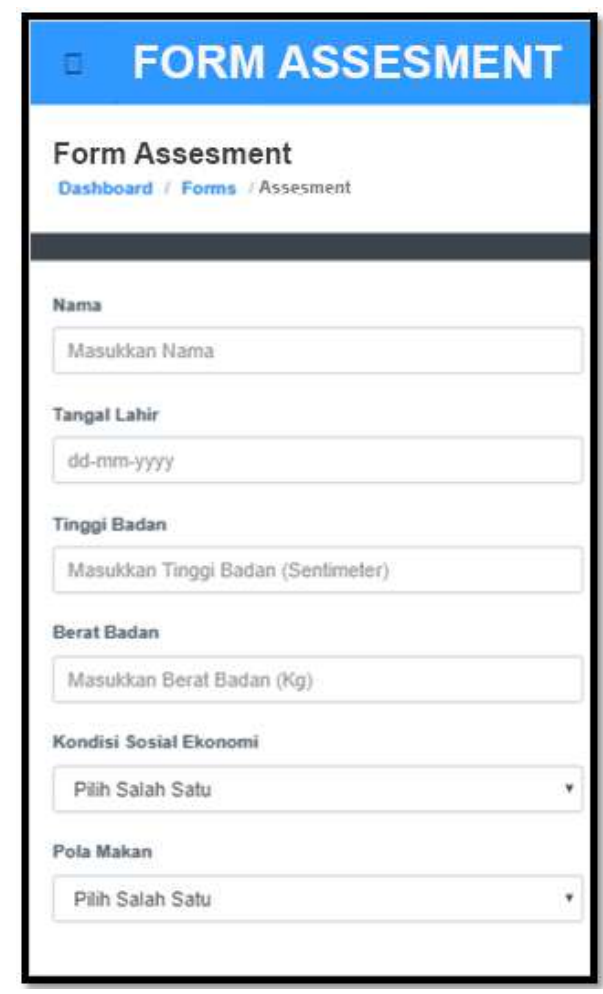

Gambar 2: Form Assesment

TRANSFORMATIKA Vol. 16, No. 1, Juli 2018: 1-13 
Gambar diatas merupakan tampilan form penilaian/ assesment status gizi remaja, terdapat beberapa inputan yang diisi antara lain Nama, Jenis Kelamin, Usia, Tinggi badan dan Berat Badan. Sistem akan menghitung secara otomatis Indexs Massa Tubuh (IMT) dan menampilkan kategori nilai IMT. Pada penilaian Sistem akan memberikan nilai otomatis berdasarkan kategori IMT yang telah dihitung sebelumnya oleh sistem. Remaja kemudian menginputkan pilihan pada sub faktor pola makan yang kemudian sistem akan memberikan nilai secara otomatis pada sub faktor pola makan yang telah diinputkan. Pada sub faktor olah raga remaja menginputkan pilihan pada sub faktor olah raga yang kemudian akan diberi nilai secara otomatis oleh sistem sesuai dengan penentuan penilaian terhadap masing-masing sub faktor. Hasil penghitungan akan ditampilkan sesuai dengan tampilan hasil pengitungan dan untuk melihat hasil perangkingan dapat dilakukan klik pada tombol hasil perangkingan.

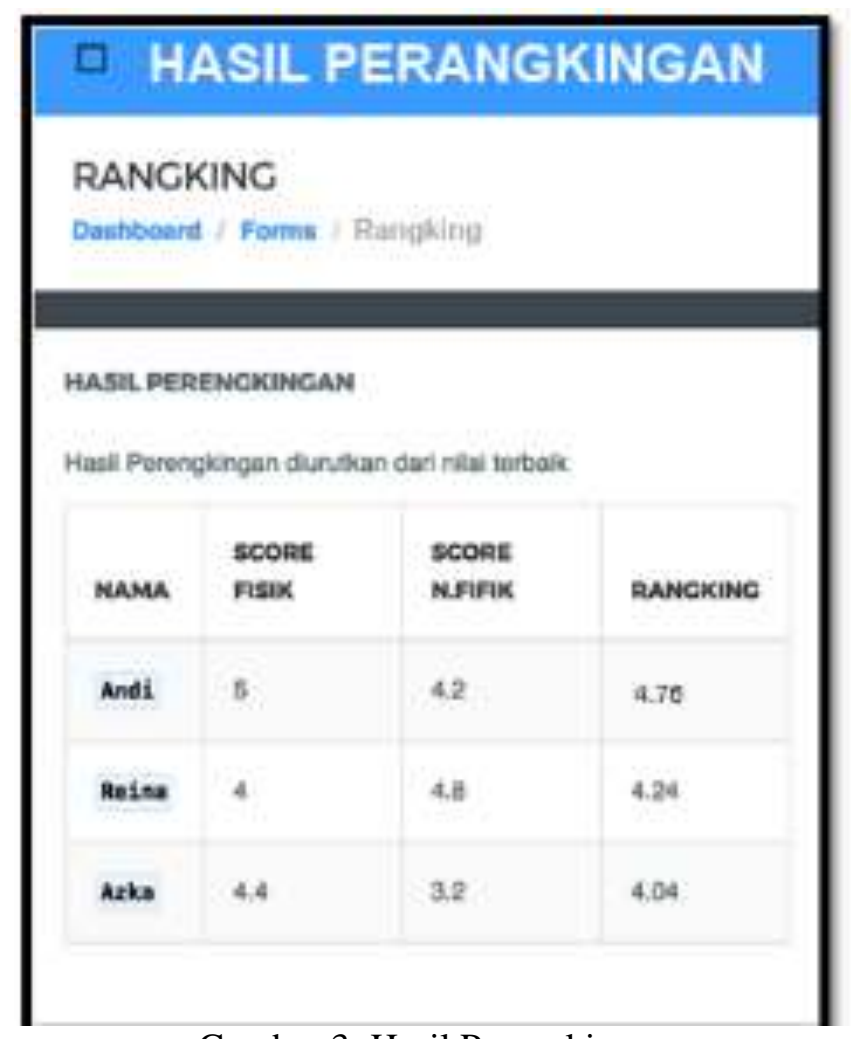

Gambar 3: Hasil Perangkingan

\subsection{Pengujian}

Pengujian internal dilakukan untuk menguji program aplikasi yang telah dibuat. Proses pengujian model black box dilakukan dengan melakukan uji coba inputan yang berupa klik icon maupun button apakah dapat berfungsi dengan baik atau tidak. Dengan pengujian black box Sistem Penentuan Status Gizi Remaja dapat diketahui apakah fasilitas inputan dan proses yang dihasilkan sudah sesuai dengan yang diharapkan.

Implementation of Profile Matching Methods in A Mobile Based Adolescent Nutritional Assesment 
Adapun form yang telah dilakukan pengujian antara lain form login administrator dan forrm assesment dengan hasil sebagai berikut:

Tabel 12: Pengujian Login

\begin{tabular}{|c|c|c|c|}
\hline \multicolumn{4}{|c|}{ Uji Coba dan Hasil Uji Login } \\
\hline Data Input & Uji Coba & Pengamatan & Kesimpulan \\
\hline Menginput User & $\begin{array}{l}\text { User sebelumnya } \\
\text { telah teregister } \\
\text { pada sistem. }\end{array}$ & \begin{tabular}{lr} 
Dapat & \multicolumn{2}{r}{ melakukan } \\
pemilihan akses yang \\
sesuai dengan level \\
user
\end{tabular} & $\begin{array}{l}\text { [X] Diterima } \\
\text { [ ] Ditolak }\end{array}$ \\
\hline Klik tombol login & $\begin{array}{lr}\text { Data } & \text { masuk } \\
\text { kedalam } & \text { sistem } \\
\text { sesuai } & \text { dengan } \\
\text { segmentasinya. }\end{array}$ & $\begin{array}{l}\text { Tombol login berfungsi } \\
\text { sesuai dengan baik }\end{array}$ & $\begin{array}{l}\text { [X] Diterima } \\
\text { [ ] Ditolak }\end{array}$ \\
\hline Tombol Close & $\begin{array}{l}\text { Keluar } \\
\text { Membatalkan } \\
\text { proeses }\end{array}$ & $\begin{array}{l}\text { Aplikasi menutup/ } \\
\text { close }\end{array}$ & $\begin{array}{l}\text { [X] Diterima } \\
\text { [ ] Ditolak }\end{array}$ \\
\hline
\end{tabular}

\begin{tabular}{|c|l|l|l|l|}
\hline \multicolumn{9}{|c|}{ Uji Cobadan Hasil Pengujian (Data Salah) } \\
\hline Data Input & \multicolumn{2}{|c|}{ Uji Coba } & \multicolumn{1}{c|}{ Pengamatan } & \multicolumn{1}{c|}{ Kesimpulan } \\
\hline Menginput User & $\begin{array}{l}\text { Input Data User } \\
\text { yang }\end{array}$ & $\begin{array}{l}\text { User tidak dapat } \\
\text { teregister dalam } \\
\text { sistem }\end{array}$ & $\begin{array}{l}\text { melakukan login dan } \\
\text { text box kosong }\end{array}$ & [ ] Ditolak \\
& & & \\
\hline
\end{tabular}

Tabel 13: Pengujian Proses Assesment

\begin{tabular}{|c|c|c|c|c|}
\hline \multicolumn{5}{|c|}{ Uji Coba dan Hasil Pengujian (Cara Benar) } \\
\hline Dat & Input & Yang diharapkan & Pengamatan & Kesimpulan \\
\hline $\begin{array}{l}\text { Jenis } \\
\text { Usia, } \\
\text { Badan, } \\
\text { Badan }\end{array}$ & $\begin{array}{r}\text { Kelamin, } \\
\text { Tinggi } \\
\text { Berat }\end{array}$ & $\begin{array}{lr}\text { Nilai IMT/U dan } \\
\text { Kategori IMT/U } \\
\text { serta skor } \\
\text { akategori } \\
\text { otomatis }\end{array}$ & $\begin{array}{l}\text { Nilai IMT/U dan } \\
\text { Kategori IMT/U serta } \\
\text { skor kategori muncul } \\
\text { otomatis }\end{array}$ & $\begin{array}{l}\text { [X] Diterima } \\
\text { [ ] Ditolak }\end{array}$ \\
\hline
\end{tabular}

\begin{tabular}{|c|l|l|l|}
\hline \multicolumn{5}{|c|}{ Uji Coba dan Hasil Pengujian (Data Salah) } \\
\hline \multicolumn{1}{|c|}{ Data Input } & Yang diharapkan & \multicolumn{1}{|c|}{ Pengamatan } & \multicolumn{1}{|c|}{ Kesimpulan } \\
\hline Usia <12 tahun & $\begin{array}{l}\text { Untuk mengetahui } \\
\text { tingkat validitas } \\
\text { inputan usia remaja }\end{array}$ & $\begin{array}{l}\text { Muncul pesan } \\
\text { kesalahan input usia, } \\
\text { proses berhenti dan }\end{array}$ & [X D ] Diterima \\
& $\begin{array}{l}\text { adalah 12 s.d 18 } \\
\text { tahun }\end{array}$ & $\begin{array}{l}\text { konfirmasi input data } \\
\text { usia dengan sesuai } \\
\text { ketentuan }\end{array}$ & \\
\hline
\end{tabular}

TRANSFORMATIKA Vol. 16, No. 1, Juli 2018: 1-13 


\section{Kesimpulan}

Metode Profile Matching sebagai mesin inferensi dapat diimplementasikan dalam sistem penentuan status gizi ini dengan terlebih dahulu menentukan masing-masing score untuk core factor dan scondary factor yang ada dalam aspek fisik dan non fisik sebagai aspek penilaian dalam penentuan status gizi remaja. Aplikasi yang dibangun dengan berbasis mobile dapat digunakan untuk penghitungan status gizi remaja dan menghasilkan informasi hasil perangkingan untuk kegiatan assesment status gizi remaja.

\section{References}

[1] Dariyo, Psikologi Perkembangan Remaja, Bogor: Ghalia Indonesia, 2004.

[2] V. A. V. Setyawati, Penentuan Status Gizi dalam Perspektif Kesehatan Masyarakat, Semarang:: Udinus Press, 2014.

[3] E. Rimawati dan V. A. V. Setyawati, "Remaja Sebagai Target Westernisasi Pangan.," dalam Seminar Pangan Nasional, 2015..

[4] H. Lestiawan dan C. Saputro, “ http://eprints.dinus.ac.id,” [Online]. Available: http://eprints.dinus.ac.id/4790/. [Diakses 5 Mei 2017].

[5] N. Fidiantoro, "Model Penentuan Status Gizi Balita di Puskesmas," Jurnal Sarjana Teknik Informatika, vol. vol. 1, pp. 367-373, 2013.

[6] Kusrini, Konsep dan Aplikasi Sistem Pendukung Keputusan, Yogyakarta: C.V Andi Offset, 2007.

[7] R. Handojo, "Pembuatan Aplikasi SistemPendukung Keputusan untuk Proses Kenaikan Jabatan dan Perencanaan Karir pada PT. X.," Jurusan Teknik Informatika Universitas KP Surabaya, 2005.

[8] V. A. V. Setyawati, Penentuan Status Gizi Dalam Perspektif Kesehatan Masyarakat Edisi II, Semarang: UDINUS Press , 2015. .

[9] B. A. Herlambang, F. M. Dewanto dan A. T. Harjanta, "Perancangan Sistem Penentuan Status Gizi Remaja Berbasis Mobile," dalam Seminar Nasional Hasil Penelitian (SNHP) -VIII, Semarang, 2017. 